\title{
PEMANFAATAN SISTEM PEMANENAN AIR HUJAN (RAINWATER HARVESTING SYSTEM) DI PERUMAHAN BONE BIRU INDAH PERMAI KOTA WATAMPONE DALAM RANGKA PENERAPAN SISTEM DRAINASE BERKELANJUTAN
}

\author{
Ilham Ali ${ }^{1}$, Suhardjono ${ }^{2}$, Andre Primantyo Hendrawan ${ }^{2}$ \\ ${ }^{1}$ Mahasiswa Magister Teknik Pengairan, Fakultas Teknik, Universitas Brawijaya, Malang \\ ${ }^{2}$,Dosen Jurusan Teknik Pengairan, Fakultas Teknik, Universitas Brawijaya, Malang \\ 1ilhamali_sdabone@yahoo.co.id, 2suhardjono@yahoo.com,3aphendra05@yahoo.com
}

\begin{abstract}
ABSTRAK: Perumahan Bone Biru Indah Permai Kota Watampone terletak di Kabupaten Bone Propinsi Sulawesi Selatan. Permasalahan sumber daya airyang terjadi di perumahan ini, adalah; di musim hujan, luapanaliran drainase seringkali mengakibatkan terjadinya genangan pada jalan-jalan perumahan dan rumah-rumah penduduk, sementara di musim kemarau,terjadi kelangkaan air bersih. Penelitian ini mengkaji penerapan sistem drainase berkelanjutandengan teknik pemanenan air hujan (PAH), dengan tujuan untuk mengetahui besaran potensi curah hujan yang dapat dipanen dan sisa limpasan yang harus di-manage oleh sistem drainase eksisting, serta untukmenentukan besaran kapasitas sarana PAH yang dibutuhkan dalam memenuhi keperluan suplai air bersih penduduk. Potensi air hujan dihitung dengan menggunakan tinggi hujan harian rata-rata bulanan yang diperoleh dari Metode Rata-rata Aritmetik. Kapasitas sarana PAH ditentukan dengan Metode Simulasi Tampungan Bulanan. Limpasan permukaan rencana dihitung dengan Metode Rasional.Dari hasil penelitian diperoleh;potensi curah hujan yang dapat dipanendari permukaan atap sebesar 147.009,86m3 per tahun, sisa limpasan hujan yang bersumber dari atap sebesar 25.829,86 m3per tahun dantotal kapasitas tampungan sarana PAH yang dibutuhkan sebesar 4.743,20 m3. Dengan penerapan sistem PAH, mampu mereduksi jumlah limpasan drainase yang terjadi sebesar 85,38\% yakni $7835,814 \mathrm{~m} 3$ dari $9178,032 \mathrm{~m} 3$ total limpasan yang terjadi, sekaligus juga dapat mengefektifkan fungsi saluran-saluran dan gorong-gorong drainase eksisting yang ada di perumahan ini.
\end{abstract}

Kata kunci: sistem pemanenan air hujan, sistem drainase berkelanjutan.

\begin{abstract}
Bone Biru Indah Permai Residence City of Watamponelied in Bone Regency, Province of South Sulawesi. Problems of water resources that happenedin this residence, were; in rainy seasons, overflow of drainage caused inundation on resindence's roads surfaces and inhabitants houses alwaysly, in the other side, in dry seasons, fresh water scarecity was occured. This research studying the implementation of sustainable drainage system by using rainwater harvesting system, with aims; to know how much potency of rainfall that can be harvested andremaining runoff must be managed by existing drainage system, and also to determine how big capacity of rainwater harvesting storage that needed to fulfill residence's inhabitant fresh water supply needs. Potency of rainwater was calculated by using monthly average rainfall height that obtained from height of monthly average daily-rainfallwhich was determined with Arithmatic Average Method. Capacity of the rainwwater harvesting storages was designed by using Monthly Storage SimulationMethod. Design surface runoff was calculated by using Rational Method. Result of research showed that; there were 147.009,85 m3 in a year potency of rainwater that could be harvested from rooftopsurfaces, 25.829,86 m3 rooftopsrunoff which still remained in every year and 4.743,20 $\mathrm{m} 3$ the total of capacity of rainwater harvesting storage that needed. With the implementation of rainwater harvesting system, can reduce $85,38 \%$ i.e. $7835,814 \mathrm{~m} 3$ of 9178,032 $\mathrm{m} 3$ the total drainage run-off and in the same time can make the functions of the channels and culverts in this residence to be more efectively too.
\end{abstract}

Keywords: rainwter harvesting system, sustainable drainage system.

Perumahan Bone Biru Indah Permai Kota Watampone terletak di Kabupaten Bone
Propinsi Sulawesi Selatan, memiliki luas 11,230 Hektar dan jumlah hunian sebanyak 658 
unit rumah serta sarana ibadah sebanyak 1 unit mesjid. Secara geografis perumahan ini terletak antara $04^{\circ} 33^{\prime} 37,79^{\prime \prime}-04^{0} 33^{\prime} 51,67^{\prime \prime}$ LS dan $120^{\circ} 19^{\prime} 58,02^{\prime \prime}-120^{\circ} 20^{\prime} 17,85^{\prime \prime}$ BT. Secara administratif sebagian besar wilayah perumahan ini terletak di Kelurahan Biru Kecamatan Tanete Riattang dan sebagiannya lagi terletak di Kelurahan Tibojong Kecamatan Tanete Riattang Timur. Kota Watampone termasuk dalam kategori Kota Sedang, dengan jumlah penduduk (hingga tahun 2014) 140.483 jiwa (Kabupaten Bone Dalam Angka 2015. BPS Kabupaten Bone. 2015).

Dua permasalahan utama yang sering terjadi terkait dengan pengelolaan sumber daya air di perumahan ini, adalah; di musim hujan, luapan (overflow) aliran drainase seringkali mengakibatkan terjadinya genangan pada jalanjalan perumahan dan rumah-rumah penduduk, sementara di musim kemarau, sumur-sumur gali penduduk mengalami kekeringan sehingga untuk memenuhi kebutuhan air bersih seharihari, penduduk perumahan mesti mendatangkan dari luar perumahan (membeli).

Tujuan utama yang ingin dicapai pada penelitian ini adalah: untuk mengetahui besaran potensi air hujan yang dapat disimpan oleh rainwater harvesting system (sistem pemanenan air hujan (PAH)) dan sisa limpasan yang harus di-manage oleh sistem drainase di perumahan Bone Biru Indah Permai Watampone; dan untuk mengetahui besaran kapasitas sarana PAH yang dibutuhkan untuk keperluan suplai air bersih penduduk perumahan Bone Biru Indah Permai Watampone setiap bulannya terkhusus ketika musim kering.

Sustainable drainage system (SuDS) adalah suatu teknik yang digunakan dalam memanage air hujan yang jatuh di atas permukaan atap-atap dan permukaan-permukaan lainnya melalui serangkaian tindakan, yang mana tujuan utamanya adalah untuk mengontrol laju aliran dan volume limpasan permukaan untuk mengurangi resiko terjadinya banjir dan pencemaran air serta dalam rangka mengurangi tekanan terhadap jaringan drainase (sewerage network) dan dalam rangka meningkatkan biodiversity dan kenyamanan lokal (local amenity) (DEFRA, 2011). Konsep dasar pengembangan drainase berkelanjutan adalah meningkatkan daya guna air, menimimalkan kerugian serta memperbaiki dan konservasi lingkungan. Sehingga, prioritas utama kegiatan harus tetap ditujukan untuk mengelola limpasan permukaan dengan cara mengembangkan fasilitas untuk menahan air hujan (rainfall retention facilities) (Suripin, 2004).

Sarana penampung air hujan merupakan sarana yang difungsikan untuk menampung air hujan untuk dimanfaatkan kembali (re-use). Sistem pemanenan air hujan (PAH)- merupakan tindakan atau upaya untuk mengumpulkan air hujan yang jatuh pada bidang tadah di atas permukaan bumi, baik berupa atap bangunan, jalan, halaman, dan untuk skala besar berupa daerah tangkapan air (Kementerian Pekerjaan Umum: 2014). PAH dapat dilakukan dengan dua macam cara, yaitu; dengan menangkap air hujan yang berasal dari permukaan atas atap (roof catchment) dan menangkap air hujan dari permukaan tanah (ground cathment) (Asdak. 2002). Komponen paling utama yang minimal harus ada dalam suatu sistem PAH ada tiga, yaitu; 1). bidang tangkap (catchment area), 2). sistem penghantar (conveyance system), dan 3 ). media penampungan (storage device). Untuk sistem PAH tangkapan atap, sistem penghantar terbagi menjadi beberapa komponen, yaitu: talang air, pengalih limpasan pertama, pipa penghantar, bak kontrol, dan intalasi saringan.

Persamaan - persamaan utama yang digunakan, diantaranya; debit limpasan permukaan menggunakan Metode Rasional dengan persamaan (Suhardjono. 2015):

$$
Q=0,00278 . C . I . A
$$

Dengan :

$\mathrm{Q}=$ debit limpasan rencana $\left(\mathrm{m}^{3} /\right.$ detik).

$\mathrm{C}=$ koefisien limpasan (tak berdimensi).

I = intensitas hujan pada durasi yang sama dengan waktu konsentrasi dan periode ulang hujan tertentu ( $\mathrm{mm} / \mathrm{jam})$.

A = luas daerah pengaliran (hektar).

Koefisien limpasan (C) ditentukan dengan menggunakan Rumus Koefisien Limpasan Tertimbang atau $C$ equivalent, dengan persamaan (Suripin. 2004):

$$
C_{e q}=\frac{\sum_{i=1}^{n} C_{i} \cdot A_{i}}{\sum_{i=1}^{n} A_{i}}
$$

Dengan :

$\mathrm{C}_{\mathrm{eq}} \quad=$ koefisien limpasan ekivalen.

$\mathrm{C}_{\mathrm{i}} \quad=$ koefisien limpasan sub-sub DAS/subsub DPS. 
$\mathrm{A}_{\mathrm{i}} \quad=$ luas masing-masing sub DAS/sub DPS

Waktu konsentrasi dihitung dengan persamaan:

$$
t_{c}=t_{o}+t_{d}
$$

Dengan :

$\mathrm{t}_{\mathrm{c}}=$ waktu konsentrasi (menit).

$\mathrm{t}_{\mathrm{o}}=$ waktu yang diperlukan air untuk mengalir di permukaan lahan sampai saluran terdekat (menit).

$\mathrm{t}_{\mathrm{d}}=$ waktu perjalanan dari pertama masuk saluran sampai titik keluaran (menit).

Waktu pengaliran lahan (overland flow, $t_{o}$ ) dihitung dengan menggunakan Rumus Kinematic Wave untuk jarak pengaliran pendek $(\mathrm{L}<130 \mathrm{~m})$, sesuai dengan prosedur yang disarankan oleh USDT (US. Department of Transportation) dalam Urban Drainage Design Manual (Brown, S.A., dkk. 2009), dengan persamaan:

$$
t_{o}=\frac{6,92}{I^{0,4}} \cdot\left(\frac{n \cdot L}{\sqrt{S}}\right)^{0,6}
$$

Dengan :

$\mathrm{t}_{\mathrm{o}} \quad=$ waktu tempuh overland flow (menit)

$\mathrm{n} \quad=$ koefisien kekasaran Manning

$\mathrm{L} \quad=$ panjang pengaliran $(\mathrm{m})$

I $\quad=$ intensitas curah hujan $(\mathrm{mm} / \mathrm{jam})$

$\mathrm{S}=$ kemiringan permukaan daerah pengaliran $(\mathrm{m} / \mathrm{m})$

Untuk menghitung waktu pengaliran lahan (overland flow, $t_{o}$ ) yang terjadi dengan menggunakan metode ini, dilakukan dengan cara iterasi atau coba-coba. Hal ini dikarenakan nilai $t_{\mathrm{c}}$ bergantung pada nilai I, sementara dalam kasus ini nilai I belum diketahui, sehingga nilai I mesti ditentukan dahulu. Penentuan nilai I diperoleh dengan menggunakan kurva atau lengkung IDF dari hujan rencana sesuai dengan kala ulang terpilih atau dengan pendekatan Rumus Mononobe (Suripin. 2004), sebagai berikut:

$$
I=\frac{R_{24}}{24} x\left(\frac{24}{t}\right)^{2 / 3}
$$

Dengan :

$$
\begin{array}{ll}
\mathrm{I} & =\text { intensitas hujan }(\mathrm{mm} / \mathrm{jam}) \\
\mathrm{t} & =\text { lamanya hujan }(\mathrm{jam}) \\
\mathrm{R}_{24} & =\text { curah hujan maksimum harian }(\mathrm{mm}, \\
& \text { selama } 24 \text { jam) }
\end{array}
$$

Untuk menghitung waktu tempuh aliran yang terjadi pada saluran $\left(t_{d}\right)$ digunakan persamaan (Brown, S.A., dkk. 2009):

$$
t_{d}=\frac{L}{(60 . V)}
$$

dimana;

$$
V=\frac{1}{n} \cdot R^{2 / 3} \cdot S^{1 / 2}
$$

Dengan :

$\mathrm{t}_{\mathrm{d}}=$ waktu tempuh aliran dalam saluran (menit)

$\mathrm{L} \quad=$ panjang pengaliran dalam saluran $(\mathrm{m})$

$\mathrm{V}=$ kecepatan aliran dalam saluran ( $\mathrm{m} /$ detik)

$\mathrm{n} \quad=$ koefisien kekasaran Manning

$\mathrm{R}=$ Jari-jari hidrolis (luas penampang basah dibagi dengan keliling basah) (m)

$\mathrm{S}=$ kemiringan saluran $(\mathrm{m} / \mathrm{m})$

Debit air kotor buangan penduduk merupakan hasil kali antara jumlah penduduk dengan debit air buangan maksimum per orang. Debit air buangan maksimum merupakan hasil kali antara total kebutuhan air bersih per hari (domestik dan non-domestik termasuk faktor kehilangan 30\%) dengan faktor air buangan 70\% (Andawayanti \& Prasetyorini. 2007).

Untuk keperluan desain sistem PAH atap (rooftop rainwater harvesting), volume limpasan hujan dari atap dapat dihitung dengan persamaan (Anonim. 2012):

$$
V_{h}=C \cdot t_{h} \cdot A
$$

Dengan :

$\mathrm{V}_{\mathrm{h}}=$ volume limpasan hujan yang dapat dipanen (liter).

$\mathrm{C}=$ koefisien limpasan berdasarkan jenis atap (tak berdimensi).

$t_{h}=$ tinggi curah hujan harian rata-rata bulanan atau tahunan (mm).

A = luas proyeksi horisontal atap $\left(\mathrm{m}^{2}\right)$.

Hubungan antara debit dan volume air hujan yang dapat ditampung dari permukaan atap, dinyatakan dengan persamaan:

$$
Q=\frac{V_{h}}{t_{c}}
$$

Dengan :

$\mathrm{Q}=$ debit air hujan yang melimpas dari permukaan atap (dalam $\mathrm{m}^{3} /$ detik). 
$\mathrm{V}_{\mathrm{h}}=$ volume air hujan yang melimpas dari permukaan atap (Persamaan (2-8), $\mathrm{m}^{3}$ ).

$t_{c}=$ waktu pengaliran hujan mulai dari atap hingga ke media penampungan (waktu konsentrasi, detik).

Perhitungan besar kebutuhan air didasarkan Kriteria Perencanaan Analisis Kebutuhan Air Ditjen Cipta Karya Departemen Pekerjaan Umum (1996).

Dalam perencanaan kapasitas sarana tampungan $\mathrm{PAH}$, digunakan Metode Neraca Air Bulanan.

\section{BAHAN DAN METODE}

\section{Data Yang Digunakan}

Data yang digunakan terbagi menjadi 2 (dua) jenis, yaitu data primer yang diperoleh dari survey langsung di lapangan dan data sekunder yang diperoleh dari instansi terkait.

Data primer meliputi data kondisi jalan dan saluran eksisting, informasikondisi muka air tanah, tata guna lahan perumahan, data kaplingan dan perumahan serta hasil evaluasi visual kondisi saluran drainase yang ada di lokasi studi.

Data sekunder meliputi album data curah hujan selama 36 tahun (1980-2015) dari 3 (tiga) stasiun curah hujan manual (non-otomatis), yaitu; SCH. Bend. Palakka, SCH. BPA.IV Biru dan SCH BPA. VIII Talungeng, yang diperoleh dari Dinas Sumber Daya Air Propinsi Sulawesi Selatan dan Dinas Pekerjaan Umum Dan Sumber Daya Air Kabupaten Bone. Data jumlah penduduk diperoleh dari Badan Pusat Statistik Kabupaten Bone. Serta beberapa informasi dan data yang terkait dengan pengelolaan sistem drainase Kota Watampone yang diperoleh dari Dinas Permukiman dan Tata Ruang Kabupaten Bone. Dasar asumsi dan beberapa ketetapan teknis mengacu pada ketentuan, standar maupun pedoman teknis yang berlaku.

\section{Tahapan Analisis}

Tahapan analisis yang ditempuh dikategorikan menjadi 3 (tiga) tahapan, yaitu: tahapan analisis hujan dan limpasan rencana (analisis hidrologi, AH), tahapan perencanaan kapasitas sarana PAH yang akan digunakan untuk keperluan konservasi air bersih, tahapan evaluasi jaringan drainase eksisting dan penerapan sistem PAH terhadap reduksi limpasan serta tahapan perencanaan dan usulan penanganan kelebihan limpasan yang masih mengakibatkan overflow pada saluran dan gorong-gorong.

Tahapan analisis hujan untuk penentuan kapasitas sarana penampungan PAH mencakup; analisis tinggi hujan harian rata-rata (dipilih metode tinggi hujan rata-rata tahunan (aritmetik)), tinggi hujan harian rata-rata bulanan, potensi curah hujan yang dapat dipanen, serta volume curah hujan yang dapat ditampung.

Tahapan analisis hujan untuk penentuan tinggi hujan rencana dalam rangka evaluasi sistem jaringan drainase mencakup; penentuan hujan harian maksimum, hujan harian maksimum rata-rata daerah (menggunakan metode rata-rata aljabar), uji pemilihan distribusi, analisis distribusi frekuensi, dan uji kesesuaian distribusi.

Adapun tahapan analisis limpasan rencana mencakup; penentuan koefisien limpasan, pemilihan kala ulang, penentuan intensitas curah hujan, serta penentuan waktu konsentrasi aliran.

Prosedur perencanaan kapasitas sarana tampungan PAH dengan menggunakan Metode Neraca Air Bulanan sebagai berikut:

i. Dapatkan data curah hujan bulanan selama setahun yang mencakup periode kering dan periode basah.

ii. Estimasi potensi volume hujan yang dapat ditangkap dari atap berdasarkan luas atap dan koefisien limpasannya (Persamaan (2-8).

iii. Estimasi kebutuhan bulanan berdasarkan jumlah pengguna air, kebutuhan atau konsumsi air per orang per hari dan jumlah rata-rata hari selama sebulan, dengan persamaan berikut:

$$
D_{m}=n \cdot D_{d} \cdot N_{m}
$$

Dengan :

$\mathrm{D}_{\mathrm{m}} \quad=$ total kebutuhan air bulanan (liter).

$\mathrm{n} \quad=$ jumlah anggota keluarga pengguna air (orang).

$\mathrm{D}_{\mathrm{d}}=$ kebutuhan air bersih harian (liter/orang/hari).

$\mathrm{N}_{\mathrm{m}} \quad$ = jumlah hari tiap bulan (hari, contoh: Januari: 30 hari).

iv. Menggunakan volume tangkapan air bulanan dan estimasi kebutuhan air bulanan untuk menghitung kapasitas penampungan minimum yang dibutuhkan. 
v. Proses perhitungan disajikan dalam format tabular (Tabel 1).

Tabel 1. Form tabel simulasi kapasitas media penyimpanan sistem PAH dengan metode neraca air

\begin{tabular}{|c|c|c|c|c|c|c|c|}
\hline \multicolumn{8}{|c|}{ Neraca Air Bulanan Untuk Penentuan Kapasitas Minimum Sarana PAH Untuk Penyimpanan Air } \\
\hline \multirow{5}{*}{\multicolumn{3}{|c|}{$\begin{array}{l}\text { Nama Lokasi Sub-Blok } \\
\text { Luas Tangkapan Atap (A) } \\
\text { Jenis Atap } \\
\text { Jumlah Pengguna Air (n) } \\
\text { Kebutuhan Air harian (Dd) }\end{array}$}} & : $\ldots . . . . . . .$. & & \multirow{5}{*}{\multicolumn{2}{|c|}{$\begin{array}{l}\text { Koefisien Limpasan (C) } \\
\text { Keb. Air Rumah Tangga } \\
\text { Harian (DRT }=n \times D d \text { ) }\end{array}$}} & \multirow{5}{*}{$\begin{array}{l}: \text {............. } \\
: \text {............ liter }\end{array}$} \\
\hline & & & $: \ldots \ldots \ldots . . . . m 2$ & & & & \\
\hline & & & : :............ & & & & \\
\hline & & & : $\ldots \ldots \ldots . . . .$. & & & & \\
\hline & & & : ............ liter/orang & hari & & & \\
\hline \multirow{3}{*}{ Bulan } & \multirow{3}{*}{$\begin{array}{c}\begin{array}{c}\text { Jumlah } \\
\text { Hari }\end{array} \\
\text { (hari) }\end{array}$} & \multirow{3}{*}{\begin{tabular}{|c} 
Hujan \\
Rerata \\
Bulanan \\
(mm)
\end{tabular}} & \multirow{2}{*}{$\begin{array}{c}\text { Volume Air Hujan } \\
\text { Yang Ditangkap } \\
\text { (Inflow) }\end{array}$} & \multirow{2}{*}{$\begin{array}{c}\text { Volume Kebutuhan } \\
\text { Air (Outflow) }\end{array}$} & \multicolumn{2}{|c|}{ Selisih Inflow - Outflow } & \multirow{3}{*}{$\begin{array}{c}\text { Kondisi Sar } \\
\text { PAH }\end{array}$} \\
\hline & & & & & Kelebihan & Kekurangan & \\
\hline & & & (liter) & (liter) & \multicolumn{2}{|c|}{ (liter) } & \\
\hline (1) & (2) & (3) & (4) $=C *(3) * A$ & (5) $=D R T *(2)$ & \multicolumn{2}{|c|}{$(6)=(4)-(5)$} & (7) \\
\hline Januari & 31 & $\ldots$ & $\ldots$ & $\ldots$ & $\ldots$ & $\ldots$ & Penuh / Kos \\
\hline Februari & 28 & $\ldots$ & $\ldots$ & $\ldots$ & $\ldots$ & $\ldots$ & Penuh / Kos \\
\hline Maret & 31 & $\ldots$ & $\ldots$ & $\ldots$ & $\ldots$ & $\ldots$ & Penuh / Kos \\
\hline April & 30 & $\ldots$ & $\ldots$ & $\ldots$ & $\ldots$ & $\ldots$ & Penuh / Kos \\
\hline Mei & 31 & $\ldots$ & $\ldots$ & $\ldots$ & $\ldots$ & $\ldots$ & Penuh / Kos \\
\hline Juni & 30 & $\ldots$ & $\ldots$ & $\ldots$ & $\ldots$ & $\ldots$ & Penuh / Kos \\
\hline Juli & 31 & $\ldots$ & $\ldots$ & $\ldots$ & $\ldots$ & $\ldots$ & Penuh / Kos \\
\hline Agustus & 31 & $\ldots$ & $\ldots$ & $\ldots$ & $\ldots$ & $\ldots$ & Penuh / Kos \\
\hline September & 30 & $\ldots$ & $\ldots$ & $\ldots$ & $\ldots$ & $\ldots$ & Penuh / Kos \\
\hline Oktober & 31 & $\ldots$ & $\ldots$ & $\ldots$ & $\ldots$ & $\ldots$ & Penuh / Kos \\
\hline Nopember & 30 & $\ldots$ & $\ldots$ & $\ldots$ & $\ldots$ & $\ldots$ & Penuh / Kos \\
\hline Desember & 31 & $\ldots$ & $\ldots$ & $\ldots$ & $\ldots$ & $\ldots$ & Penuh / Kos \\
\hline JUMLAH & 365 & $\ldots$ & ... & $\ldots$ & ... & $\ldots$ & \\
\hline \multicolumn{7}{|c|}{ Sisa pemakaian tahunan (dalam satuan Liter) } & .. \\
\hline \multirow{2}{*}{\multicolumn{5}{|c|}{ Kapasitas minimum sarana PAH sub-blok Aa : }} & \multicolumn{2}{|c|}{ dalam satuan Liter } & $\ldots$ \\
\hline & & & & & \multicolumn{2}{|c|}{ dalam satuan $\mathbf{M 3}$} & $\ldots$ \\
\hline
\end{tabular}

(Sumber: UNEP \& CEHI. 2009 dengan perubahan dan penyesuaian)

vi. Sisa pemakaian tahunan merupakan selisih antara total kelebihan air yang tidak dimanfaatkan (surplus) dengan kekurangan air dalam setahun (defisit). Kapasitas media penyimpanan minimum sama dengan besar kebutuhan air maksimum yang tidak dapat dipenuhi dalam sebulannya (besar kekurangan maksimum (Kolom (6). Kekurangan).

Bagan alir proses penelitian dapat dilihat dalam Gambar 1. 


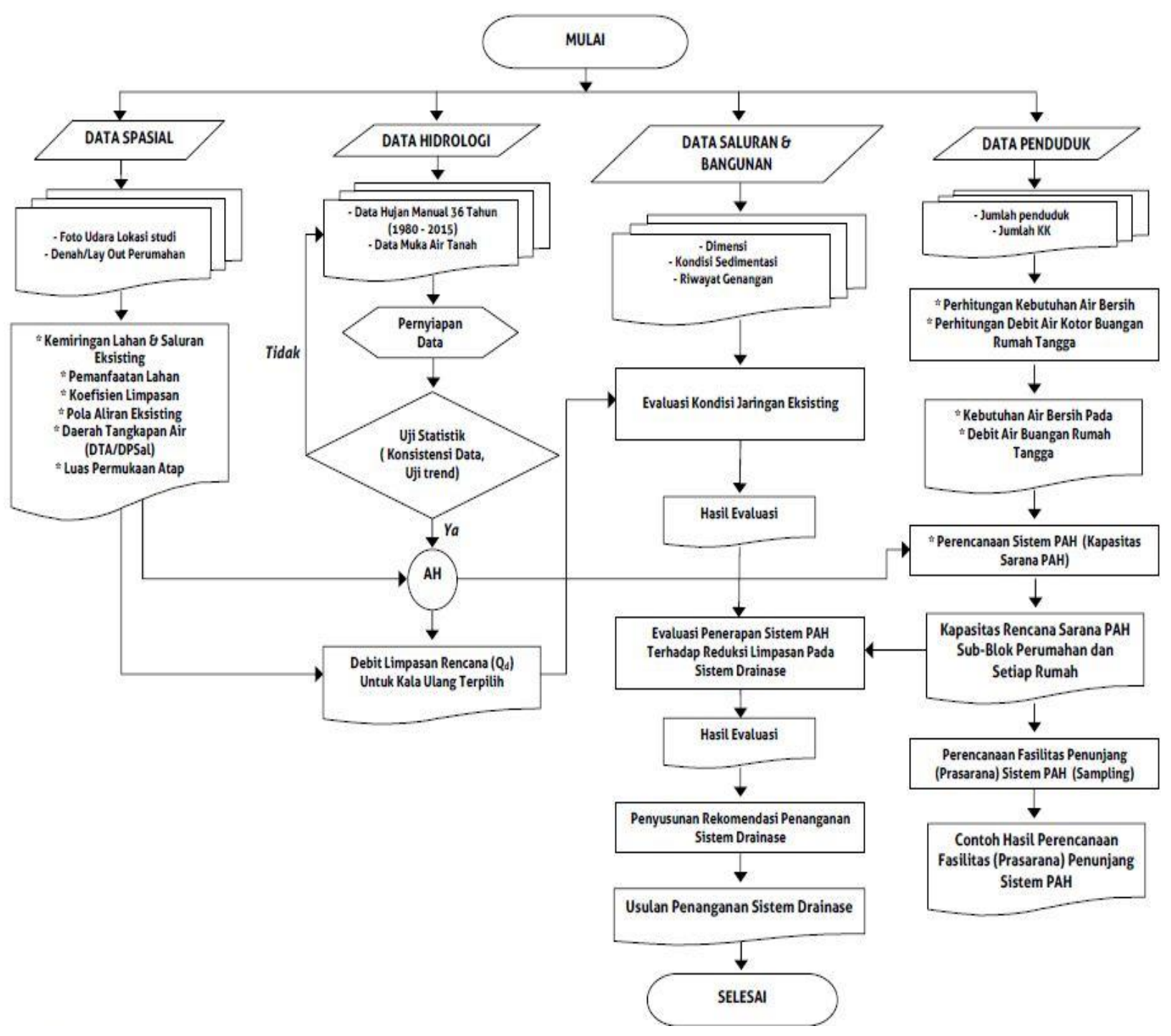

Gambar 1. Bagan alir penelitian

\section{HASIL DAN PEMBAHASAN}

\section{Uji Konsistensi}

Hasil uji konsistensi dari seri data pada ketiga stasiun hujan, yakni SCH. Bend. Palakka, SCH. BPAIV. Biru dan $\mathrm{SCH}$. BPAVIII. Talungeng, menunjukkan bahwa data dari masing-masing stasiun saling konsisten satu sama lainnya. Kurva massa ganda untuk SCH. Bend. Palakka memberikan nilai koefisien determinasi $\left(\mathrm{R}^{2}\right)=0,9981$ $(99,81 \%)$, SCH. BPA.IV Biru, $\mathrm{R}^{2}=0,9991$ $(99,91 \%)$ dan SCH. BPA.VIII Talungeng, $\mathrm{R}^{2}=$ $0,9991(99,91 \%)$.

\section{Uji Ketidak Adaan Trend}

Dari hasil analisis yang telah dilakukan sulit atau tidak ditemukan adanya pola data yang menunjukkan adanya suatu trend yang seragam (baik pola yang menunjukkan trend peningkatan nilai curah hujan tahunan maupun sebaliknya yang menunjukkan trend penurunan) dari ketiga kelompok data yang diuji untuk masing-masing stasiun yang ditinjau, sehingga memenuhi syarat untuk digunakan dalam analisis distribusi peluang (analisis frekuensi).

\section{Tinggi Hujan Harian Rata-rata Bulanan}

Tinggi curah hujan harian rata-rata di lokasi studi selama kurun waktu 36 tahun terakhir serta jumlah hari rata-ratanya, untuk bulan; Januari $=17,48 \mathrm{~mm}$ (9 hari hujan), Februari $=17,47 \mathrm{~mm}$ ( 8 hari hujan $)$, Maret $=$ $19,51 \mathrm{~mm}$ (11 hari hujan), April $=20,24 \mathrm{~mm}$ (13 hari hujan), Mei $=22,98 \mathrm{~mm}$ (15 hari 
hujan), Juni $=21,31 \mathrm{~mm}$ (13 hari hujan), Juli = $19,71 \mathrm{~mm}$ (11 hari hujan), Agustus $=15,11 \mathrm{~mm}$ (6 hari hujan), September $=15,61 \mathrm{~mm}(5$ hari hujan), Oktober $=16,64 \mathrm{~mm}$ (7 hari hujan), Nopember $=15,89 \mathrm{~mm}(8$ hari hujan $)$, dan Desember $=17,63 \mathrm{~mm}$ (9 hari hujan).

\section{Tinggi Hujan Rencana}

Penentuan besar tinggi hujan rencana dengan menggunakan Distribusi Log Normal menghasilkan tinggi hujan rencana kala ulang 5 tahun sebesar 95,23 mm. Pemilihan metode Distribusi Log Normal didasarkan pada hasil uji pemilihan distribusi, dimana sebaran data yang diujikan memiliki kemiripan dengan Distribusi Log Normal. Hal ini ditunjukkan dengan adanya salah satu dari hasil uji data yang paling mendekati dengan salah satu dari parameter uji distribusi Log Normal, yaitu nilai Cs $(0,316) \approx$ 3 . $\mathrm{Cv}(3.0,308=0,923)$.

Dari hasil uji kesesuaian distribusi baik secara vertikal (Chi Kuadrat) maupun secara horisontal (Smirnov-Kolmogorov) menunjukkan bahwa penentuan tinggi hujan rencana dengan cara analisis frekuensi yang menggunakan Metode Log Normal dapat diterima.

\section{Luas Tutupan Atap Maksimum}

Yang dimaksud dengan luas tutupan atap maksimum dalam kajian ini adalah luasan tutupan atap paling besar yang dapat dicapai di lokasi studi dengan asumsi seluruh pemilik kaplingan akan memaksimalkan bangunannya, sehingga seluruh permukaan kaplingan akan tertutupi oleh atap perumahan. Luas tutupan atap ini merupakan luas daerah tangkapan atap yang dipakai dalam perhitungan air hujan yang dapat dipanen.

Hasil analisis menunjukkan luas daerah tangkapan atap maksimum yang mungkin terjadi berbanding lurus dengan luas kaplingan perumahan. Luasan yang diperoleh memiliki nilai yang bervariasi, dengan luas tangkapan atap terbesar yang dapat dicapai, berada pada sub-blok B4 dengan total luasan sebesar 2.416,36 $\mathrm{m}^{2}$, sementara luasan yang paling minimal berada pada sub-blok C1e-t dengan total luasan sebesar 116,31 m² (Gambar 2).

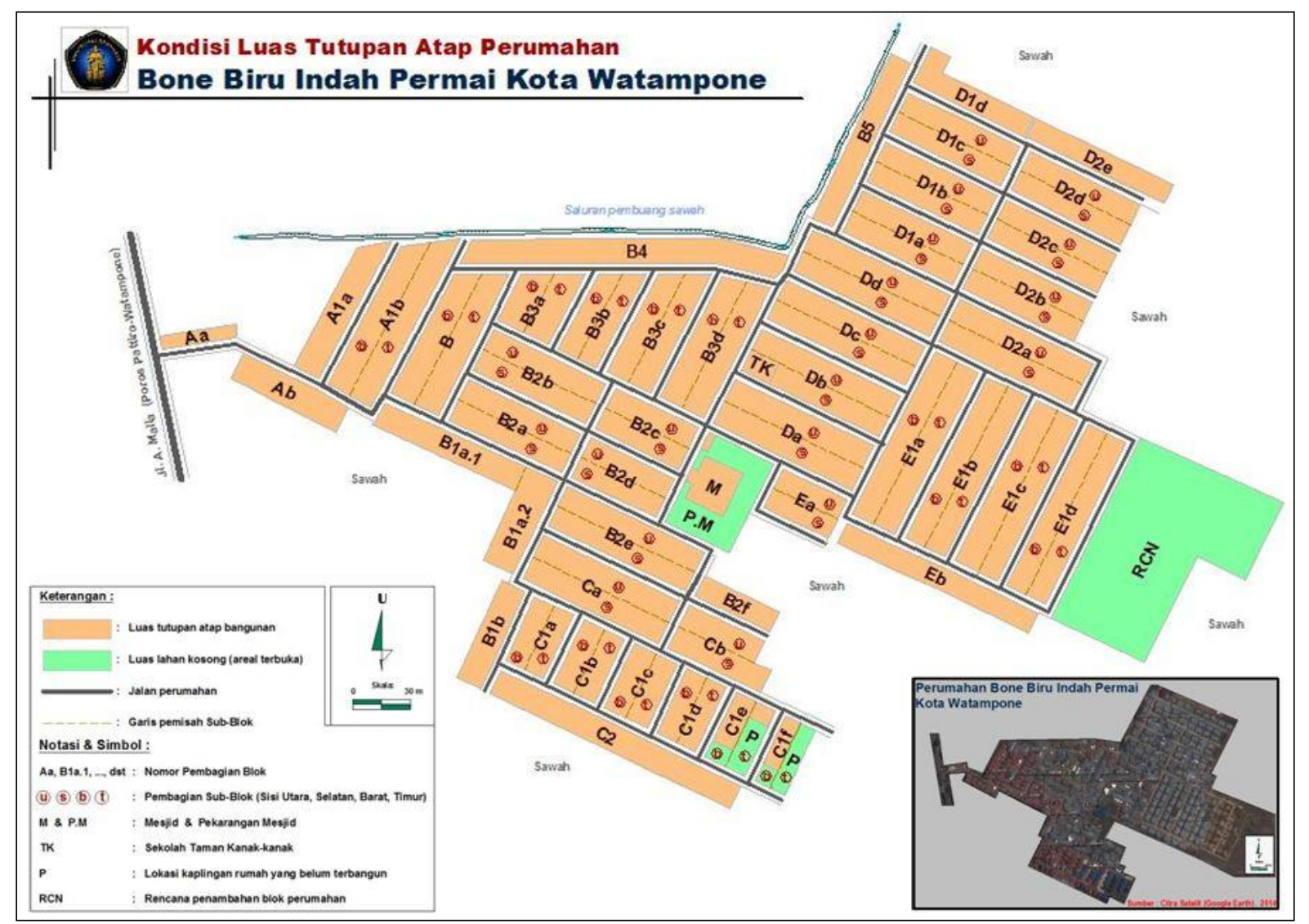

Gambar 2. Pembagian sub-blok perumahan dan estimasi luasan tangkapan atap maksimum Perumahan Bone Biru Indah Permai Kota Watampone

(Sumber: Hasil Analisis. 2016) 
Adapun total luasan atap untuk seluruh kawasan perumahan yang dapat diperoleh adalah sebesar 74.780,04 $\mathrm{m}^{2}$.

\section{Volume Air Hujan Yang Dapat Dipanen}

Umumnya jenis atap yang digunakan di lokasi studi adalah atap yang terbuat dari lembaran besi galvanis $(\mathrm{GI})$ bergelombang $(\mathrm{C}=$ 0,90). Diasumsikan faktor kehilangan air sama dengan $0 \%$, dengan kata lain seluruh air hujan yang jatuh di atas permukaan atap sedapat mungkin dapat ditangkap oleh sarana $\mathrm{PAH}$ yang digunakan.

Dari hasil analisis diperoleh bahwa potensi air hujan terbesar yang dapat dipanen dimiliki oleh sub-blok B4 yakni sebesar 4.750.314,88 liter/tahun (4.750,32 $\mathrm{m}^{3} /$ tahun), sementara potensi terkecil dimiliki oleh sub-blok $\mathrm{C} 1 \mathrm{e}-\mathrm{t}$ yakni sebesar 228.653,48 liter/tahun (228, 65 $\mathrm{m}^{3} /$ tahun). Hal ini berbanding lurus dengan luasan daerah tangkapan atap yang dapat dicapai sebagaimana telah dijelaskan pada subbahasan sebelumnya. Adapun total potensi air hujan yang dapat dipanen di perumahan ini adalah sebesar 147.009.856,03 liter/tahun (147.009,86 $\mathrm{m}^{3} /$ tahun).

Adapun jumlah volume air hujan bulanan yang dapat dipanen di kawasan Perumahan Bone Biru Indah Permai Kota Watampone ini, selengkapnya dapat dilihat dalam Tabel 2.

Tabel 2. Total volume air hujan bulanan yang dapat dipanen

\begin{tabular}{|c|c|c|c|c|}
\hline \multirow[t]{2}{*}{ Bulan } & \multirow{2}{*}{$\begin{array}{c}\text { Tinggi Hujan } \\
\text { Harian Rata- } \\
\text { Rata Bulanan } \\
\text { (mm/hari) }\end{array}$} & \multirow{2}{*}{$\begin{array}{c}\text { Jumlah Hari } \\
\text { Hujan Rata- } \\
\text { Rata Dalam } \\
\text { Tiap Bulan }\end{array}$} & \multicolumn{2}{|c|}{$\begin{array}{l}\text { Jumlah Volume Air Hujan Yang Dapat } \\
\text { Dipanen Tiap Bulan }\end{array}$} \\
\hline & & & (liter) & (m3) \\
\hline Januari & 17,48 & 9 & 10587956,30 & 10587,956 \\
\hline Februari & 17,47 & 8 & $9.406 .132,55$ & $9.406,13$ \\
\hline Maret & 19,51 & 11 & $14.443 .689,95$ & $14.443,69$ \\
\hline April & 20,24 & 13 & $17.708 .511,71$ & $17.708,51$ \\
\hline Mei & 22,98 & 15 & $23.199 .011,81$ & $23.199,01$ \\
\hline Juni & 21,31 & 13 & $18.644 .683,03$ & $18.644,68$ \\
\hline Juli & 19,71 & 11 & $14.591 .754,43$ & $14.591,75$ \\
\hline Agustus & 15,11 & 6 & $6.101 .602,58$ & $6.101,60$ \\
\hline September & 15,61 & 5 & $5.252 .923,91$ & $5.252,92$ \\
\hline Oktober & 16,64 & 7 & $7.839 .341,15$ & $7.839,34$ \\
\hline Nopember & 15,89 & 8 & $8.555 .434,82$ & $8.555,43$ \\
\hline Desember & 17,63 & 9 & $10.678 .814,05$ & $10.678,81$ \\
\hline & & 115 & $147.009 .856,30$ & $147.009,86$ \\
\hline
\end{tabular}

(Sumber: Hasil Analisis. 2016)

\section{Kebutuhan Air}

Menurut Kriteria Perencanaan Analisis Kebutuhan Air yang diterbitkan oleh Ditjen Cipta Karya Departemen Pekerjaan Umum (1996), Kota Watampone termasuk dalam kota Kategori III (Kota Sedang) dengan kisaran penduduk berada diantara 100.000 500.000 jiwa. Sehingga kebutuhan konsumsi air bersih untuk keperluan domestik per unit sambungan rumah menurut aturan ini, berada pada kisaran 90 - 120 liter/orang/hari.

Dipilih nilai kebutuhan air bersih harian yang tidak menghasilkan jumlah kebutuhan air bersih tahunan yang lebih besar dari potensi ketersediaan air hujan hasil tangkapan atap masing-masing sub-blok, yaitu sebanyak 100 liter/hari/orang.

\section{Kapasitas Sarana PAH}

Dari hasil simulasi dengan Metode Simulasi Tampungan, diperoleh besar kapasitas sarana PAH minimum yang harus disiapkan oleh setiap rumah yang ada di tiap sub-blok, guna memenuhi kebutuhan air bersih bulanannya (untuk kebutuhan harian 100 liter/hari/orang). Berdasarkan besaran kapasitas minimum ditetapkanlah kapasitas rencana sarana PAH yang akan digunakan oleh setiap rumah dalam setiap sub-blok di Perumahan Bone Biru Indah Permai (Tabel 3.).

Dari hasil analisis dalam Tabel 3, nampak bahwa total kapasitas rencana yang dibutuhkan di perumahan ini adalah sebesar 4.743.200 liter $\left(4.743,20 \mathrm{~m}^{3}\right)$, dengan kapaistas terbesar dari sarana PAH per sub-blok, berada pada sub-blok B4, yakni sebesar 115.900 liter $\left(115,90 \mathrm{~m}^{3}\right)$.

Total kapasitas rencana terkecil dari sarana PAH per sub-bloknya, berada pada sub-blok Aa, dengan besaran 6.400 liter $\left(6,40 \mathrm{~m}^{3}\right)$. Hal ini disebabkan karena pada sub blok B4, meskipun memiliki luas daerah tangkapan atap terbesar (yang akan berimplikasi pada besarnya potensi hujan yang dapat dipanen) yakni 2.416,36 $\mathrm{m}^{2}$, akan tetapi jumlah pengguna airnya juga besar (95 jiwa dari 19 unit rumah (19 KK)), sehingga akan membutuhkan jumlah air hujan yang besar pula dalam pemenuhan kebutuhan air bersihnya. Adapun kapasitas terkecil dari sarana PAH per sub-blok perumahan berada pada sub-blok Aa dengan besaran 6.400 liter $\left(6,4 \mathrm{~m}^{3}\right)$, dengan jumlah pengguna air sebanyak 10 jiwa dari 2 unit rumah $(2 \mathrm{KK})$.

Untuk kategori bangunan, kapasitas terbesar penyimpanan air hujan yang dibutuhkan, berada pada bangunan mesjid yakni sebesar 42.900 liter $\left(42,9 \mathrm{~m}^{3}\right)$, sedangkan untuk bangunan yang membutuhkan kapasitas sarana PAH terkecil, berada pada rumah-rumah 
yang ada di sub-blok B1a.2 yakni hanya sebesar 2.700 liter $\left(2,7 \mathrm{~m}^{3}\right)$ saja.

\section{Hubungan Antara Ketersediaan Dan Kebutuhan Air Serta Kapasitas Tampungan Sarana PAH}

Tabel 3. Kapasitas sarana PAH

\begin{tabular}{|c|c|c|c|c|c|c|}
\hline \multirow[t]{2}{*}{$\begin{array}{l}\text { No. } \\
\text { Urut }\end{array}$} & \multirow[t]{2}{*}{$\begin{array}{c}\text { Nama } \\
\text { Sub-Blok }\end{array}$} & \multirow{2}{*}{$\begin{array}{c}\text { Jumlah } \\
\text { Rumah } \\
\text { (KK) } \\
\text { (unit/KK) }\end{array}$} & \multicolumn{2}{|c|}{$\begin{array}{c}\text { Kapasitas Sarana PAH } \\
\text { Yang Direncanakan Tiap } \\
\text { Rumah (KK) }\end{array}$} & \multicolumn{2}{|c|}{$\begin{array}{c}\text { Kapasitas Rencana Sarana } \\
\text { PAH Tiap Sub-Blok } \\
\text { Perumahan }\end{array}$} \\
\hline & & & ( $m^{3} /$ unit $)$ & (liter/unit) & $\left(m^{3}\right)$ & (liter) \\
\hline 1 & $\mathrm{Aa}$ & 2 & 3,20 & $3.200,00$ & 6,40 & $6.400,00$ \\
\hline 2 & $A b$ & 6 & 3,00 & $3.000,00$ & 18,00 & $18.000,00$ \\
\hline 3 & A1a & 8 & 4,10 & $4.100,00$ & 32,80 & $32.800,00$ \\
\hline 4 & A1b-b & 9 & 5,60 & $5.600,00$ & 50,40 & $50.400,00$ \\
\hline 5 & A1b-t & 9 & 4,20 & $4.200,00$ & 37,80 & $37.800,00$ \\
\hline 6 & $B-b$ & 8 & 5,60 & $5.600,00$ & 44,80 & $44.800,00$ \\
\hline 7 & $B-t$ & 9 & 5,90 & $5.900,00$ & 53,10 & $53.100,00$ \\
\hline 8 & B3a-b & 4 & 6,20 & $6.200,00$ & 24,80 & $24.800,00$ \\
\hline 9 & B3a-t & 5 & 6,30 & $6.300,00$ & 31,50 & $31.500,00$ \\
\hline 10 & B3b-b & 5 & 6,90 & $6.900,00$ & 34,50 & $34.500,00$ \\
\hline 11 & B3b-t & 5 & 6,00 & $6.000,00$ & 30,00 & $30.000,00$ \\
\hline 12 & B3c-b & 7 & 6,50 & $6.500,00$ & 45,50 & $45.500,00$ \\
\hline 13 & $B 3 c-t$ & 8 & 6,80 & $6.800,00$ & 54,40 & $54.400,00$ \\
\hline 14 & B3d-b & 9 & 7,20 & $7.200,00$ & 64,80 & $64.800,00$ \\
\hline 15 & B3d-t & 9 & 6,70 & $6.700,00$ & 60,30 & $60.300,00$ \\
\hline 16 & B1a.1 & 10 & 6,60 & $6.600,00$ & 66,00 & $66.000,00$ \\
\hline 17 & B1a.2 & 6 & 2,70 & $2.700,00$ & 16,20 & $16.200,00$ \\
\hline 18 & B2b-u & 8 & 7,50 & $7.500,00$ & 60,00 & $60.000,00$ \\
\hline 19 & B2b-s & 8 & 7,50 & $7.500,00$ & 60,00 & $60.000,00$ \\
\hline 20 & B2a-u & 8 & 7,70 & $7.700,00$ & 61,60 & $61.600,00$ \\
\hline 21 & B2a-s & 7 & 6,60 & $6.600,00$ & 46,20 & $46.200,00$ \\
\hline 22 & B2C-U & 6 & 7,60 & $7.600,00$ & 45,60 & $45.600,00$ \\
\hline 23 & $B 2 c-s$ & 6 & 7,60 & $7.600,00$ & 45,60 & $45.600,00$ \\
\hline 24 & B2d-u & 6 & 7,90 & $7.900,00$ & 47,40 & $47.400,00$ \\
\hline 25 & B2d-s & 6 & 7,90 & $7.900,00$ & 47,40 & $47.400,00$ \\
\hline 26 & B2e-u & 10 & 8,00 & $8.000,00$ & 80,00 & $80.000,00$ \\
\hline 27 & B2e-s & 10 & 8,00 & $8.000,00$ & 80,00 & $80.000,00$ \\
\hline 28 & $\mathrm{Ca}-\mathrm{u}$ & 10 & 7,30 & $7.300,00$ & 73,00 & $73.000,00$ \\
\hline 29 & $\mathrm{Ca}-\mathrm{s}$ & 10 & 7,30 & $7.300,00$ & 73,00 & $73.000,00$ \\
\hline 30 & B2f & 6 & 8,50 & $8.500,00$ & 51,00 & $51.000,00$ \\
\hline 31 & Cb-u & 6 & 7,90 & $7.900,00$ & 47,40 & $47.400,00$ \\
\hline 32 & Cb-s & 8 & 8,40 & $8.400,00$ & 67,20 & $67.200,00$ \\
\hline 33 & B1b & 6 & 5,20 & $5.200,00$ & 31,20 & $31.200,00$ \\
\hline 34 & Cla-b & 4 & 7,00 & $7.000,00$ & 28,00 & $28.000,00$ \\
\hline 35 & C1a-t & 4 & 7,00 & $7.000,00$ & 28,00 & $28.000,00$ \\
\hline 36 & C1b-b & 4 & 6,50 & $6.500,00$ & 26,00 & $26.000,00$ \\
\hline 37 & C1b-t & 4 & 6,50 & $6.500,00$ & 26,00 & $26.000,00$ \\
\hline 38 & $c 1 c-b$ & 4 & 6,10 & $6.100,00$ & 24,40 & $24.400,00$ \\
\hline 39 & C1c-t & 4 & 6,10 & $6.100,00$ & 24,40 & $24.400,00$ \\
\hline 40 & C1d-b & 4 & 6,70 & $6.700,00$ & 26,80 & $26.800,00$ \\
\hline 41 & C1d-t & 4 & 6,70 & $6.700,00$ & 26,80 & $26.800,00$ \\
\hline 42 & C1e-b & 3 & 6,70 & $6.700,00$ & 20,10 & $20.100,00$ \\
\hline 43 & C1e-t & 1 & 6,90 & $6.900,00$ & 6,90 & $6.900,00$ \\
\hline 44 & C1f-b & 3 & 8,80 & $8.800,00$ & 26,40 & $26.400,00$ \\
\hline 45 & $\mathrm{C} 2$ & 15 & 5,20 & $5.200,00$ & 78,00 & $78.000,00$ \\
\hline
\end{tabular}

(Sumber: Hasil Analisis. 2016)

\section{Hubungan Antara Ketersediaan Dan Kebutuhan Air Serta Kapasitas Tampungan Sarana PAH}

Hubungan antara ketersediaan dan kebutuhan air serta kondisi simpanan air
Hubungan antara ketersediaan dan kebutuhan air serta kondisi simpanan air sarana PAH setiap bulan dan setiap tahunnya dapat dilihat dalam Gambar 3 dan 4.

\begin{tabular}{|c|c|c|c|c|c|c|}
\hline \multirow[t]{2}{*}{$\begin{array}{c}\text { No. } \\
\text { Urut }\end{array}$} & \multirow[t]{2}{*}{$\begin{array}{c}\text { Nama } \\
\text { Sub-Blok }\end{array}$} & \multirow{2}{*}{$\begin{array}{l}\text { Jumlah } \\
\text { Rumah } \\
\text { (KK) } \\
\text { (unit/KK) }\end{array}$} & \multicolumn{2}{|c|}{$\begin{array}{c}\text { Kapasitas Sarana PAH } \\
\text { Yang Direncanakan Tiap } \\
\text { Rumah (KK) }\end{array}$} & \multicolumn{2}{|c|}{$\begin{array}{c}\text { Kapasitas Rencana Sarana } \\
\text { PAH Tiap Sub-Blok } \\
\text { Perumahan }\end{array}$} \\
\hline & & & ( $\mathrm{m}^{3} /$ unit) & (liter/unit) & $\left(m^{3}\right)$ & (liter) \\
\hline 46 & B4 & 19 & 6,10 & $6.100,00$ & 115,90 & $115.900,00$ \\
\hline 47 & B5 & 12 & 8,00 & $8.000,00$ & 96,00 & $96.000,00$ \\
\hline 48 & Da-s & 10 & 6,90 & $6.900,00$ & 69,00 & $69.000,00$ \\
\hline 49 & Da-u & 10 & 6,90 & $6.900,00$ & 69,00 & $69.000,00$ \\
\hline 50 & Db-s & 10 & 7,50 & $7.500,00$ & 75,00 & $75.000,00$ \\
\hline 51 & Db-u & 10 & 7,50 & $7.500,00$ & 75,00 & $75.000,00$ \\
\hline 52 & DC-s & 10 & 7,90 & $7.900,00$ & 79,00 & $79.000,00$ \\
\hline 53 & Dc-u & 10 & 7,80 & $7.800,00$ & 78,00 & $78.000,00$ \\
\hline 54 & Dd-s & 10 & 7,50 & $7.500,00$ & 75,00 & $75.000,00$ \\
\hline 55 & Dd-u & 10 & 7,50 & $7.500,00$ & 75,00 & $75.000,00$ \\
\hline 56 & D1a-s & 8 & 7,60 & $7.600,00$ & 60,80 & $60.800,00$ \\
\hline 57 & D1a-u & 8 & 7,60 & $7.600,00$ & 60,80 & $60.800,00$ \\
\hline 58 & D1b-s & 8 & 7,80 & $7.800,00$ & 62,40 & $62.400,00$ \\
\hline 59 & D1b-u & 8 & 7,80 & $7.800,00$ & 62,40 & $62.400,00$ \\
\hline 60 & D1c-s & 8 & 7,90 & $7.900,00$ & 63,20 & $63.200,00$ \\
\hline 61 & D1c-u & 8 & 7,90 & $7.900,00$ & 63,20 & $63.200,00$ \\
\hline 62 & D1d & 8 & 6,80 & $6.800,00$ & 54,40 & $54.400,00$ \\
\hline 63 & Ea-u & 4 & 6,80 & $6.800,00$ & 27,20 & $27.200,00$ \\
\hline 64 & Ea-s & 4 & 6,80 & $6.800,00$ & 27,20 & $27.200,00$ \\
\hline 65 & $E b$ & 14 & 8,00 & $8.000,00$ & 112,00 & $112.000,00$ \\
\hline 66 & $E 1 a-b$ & 12 & 7,20 & $7.200,00$ & 86,40 & $86.400,00$ \\
\hline 67 & E1a-t & 12 & 7,20 & $7.200,00$ & 86,40 & $86.400,00$ \\
\hline 68 & $E 1 b-b$ & 12 & 8,10 & $8.100,00$ & 97,20 & $97.200,00$ \\
\hline 69 & E1b-t & 12 & 8,10 & $8.100,00$ & 97,20 & $97.200,00$ \\
\hline 70 & E1c-b & 12 & 7,60 & $7.600,00$ & 91,20 & $91.200,00$ \\
\hline 71 & E1c-t & 12 & 7,60 & $7.600,00$ & 91,20 & $91.200,00$ \\
\hline 72 & E1d-b & 12 & 8,20 & $8.200,00$ & 98,40 & $98.400,00$ \\
\hline 73 & E1d-t & 12 & 8,20 & $8.200,00$ & 98,40 & $98.400,00$ \\
\hline 74 & D2a-s & 10 & 7,60 & $7.600,00$ & 76,00 & $76.000,00$ \\
\hline 75 & D2a-u & 10 & 7,60 & $7.600,00$ & 76,00 & $76.000,00$ \\
\hline 76 & D2b-s & 9 & 8,50 & $8.500,00$ & 76,50 & $76.500,00$ \\
\hline 77 & D2b-u & 8 & 7,60 & $7.600,00$ & 60,80 & $60.800,00$ \\
\hline 78 & D2C-s & 8 & 8,10 & $8.100,00$ & 64,80 & $64.800,00$ \\
\hline 79 & D2c-u & 8 & 8,10 & $8.100,00$ & 64,80 & $64.800,00$ \\
\hline 80 & D2d-s & 8 & 7,80 & $7.800,00$ & 62,40 & $62.400,00$ \\
\hline 81 & D2d-u & 8 & 7,80 & $7.800,00$ & 62,40 & $62.400,00$ \\
\hline 82 & $\mathrm{D} 2 \mathrm{e}$ & 10 & 8,00 & $8.000,00$ & 80,00 & $80.000,00$ \\
\hline \multicolumn{2}{|c|}{ JUMLAH } & 364 & 281,90 & $281.900,00$ & $2.770,60$ & $2.770 .600,00$ \\
\hline 83 & $M$ & 1 & 42,90 & $42.900,00$ & 42,90 & $42.900,00$ \\
\hline \multicolumn{2}{|c|}{ JUMLAH } & & 324,80 & $324.800,00$ & $2.813,50$ & $2.813 .500,00$ \\
\hline
\end{tabular}

sarana PAH setiap bulan dan setiap tahunnya dapat dilihat dalam Gambar 3 dan 4.

Dari Gambar 3, nampak dengan jelas bahwa pada bulan Agustus - Nopember, terjadi kekurangan air dalam memenuhi kebutuhan penduduk di bulan-bulan tersebut. Sehingga 
dengan adanya penyimpanan air pada bulanbulan basah (yakni Februari - Juli) diharapkan mampu menutupi kekurangan-kekurangan air pada bulan-bulan kering tersebut. Adapun Gambar 4 memperlihatkan bahwa dengan curah hujan yang ada (jumlah rata-rata bulanan) dan berdasarkan kebutuhan harian air bersih 100 liter/hari/orang, maka setelah bulan Maret hingga Desember, kondisi sarana-sarana PAH yang ada diperumahan ini akan mencapai volume simpanan maksimum (penuh), sehingga sisa limpasan hujan yang berasal dari atap-atap perumahan tidak akan tertampung lagi dalam sistem PAH tetapi akan melimpas bersama air hujan yang jatuh dipermukaan jalan dan lahan kosong lainnya menjadi limpasan drainase yang harus diakomodir oleh sistem drainase yang ada di lokasi ini.

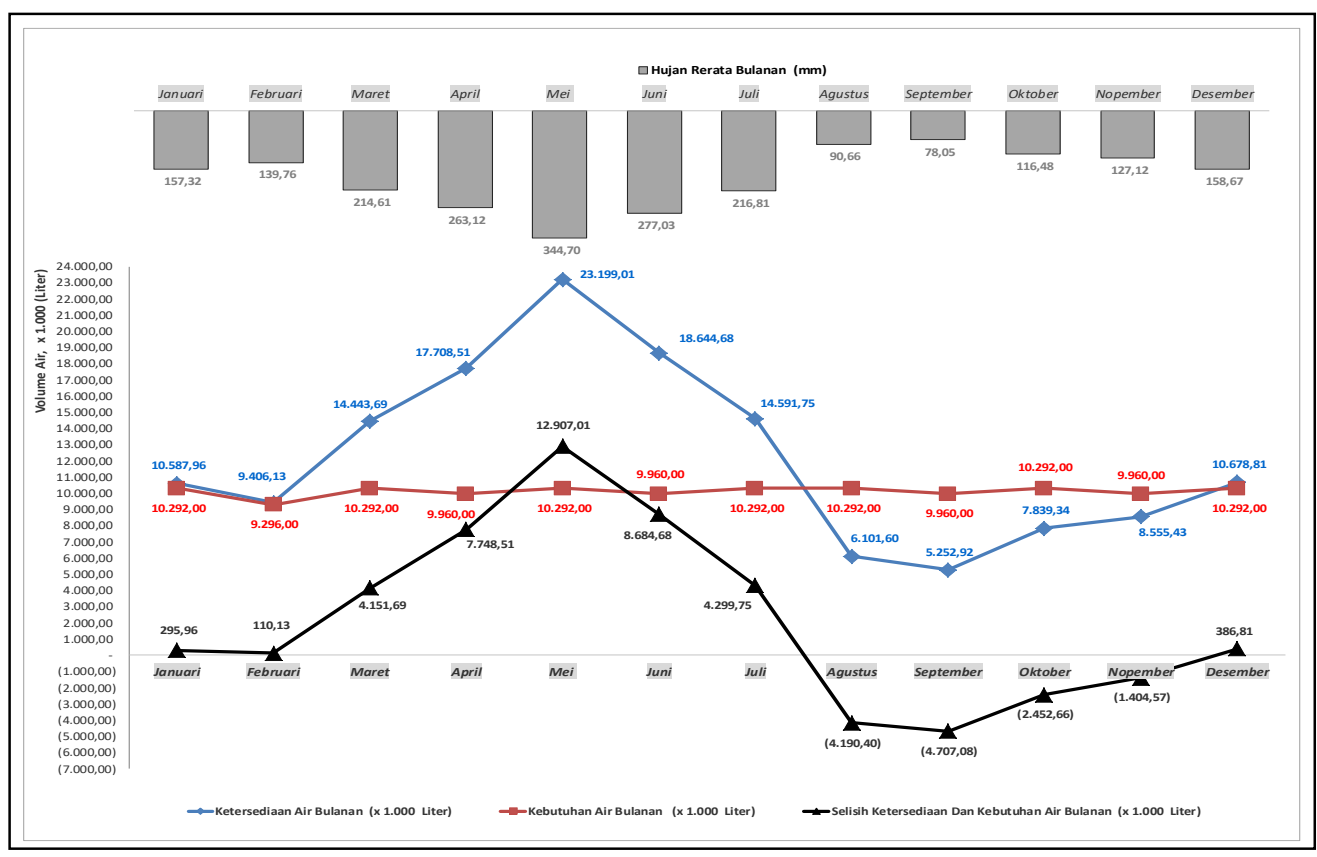

Gambar 3. Hubungan Antara Ketersediaan Air Hujan, Kebutuhan Air Bersih Dan Selisih Ketersediaan - Kebutuhan (Sumber: Hasil Analisis. 2016)

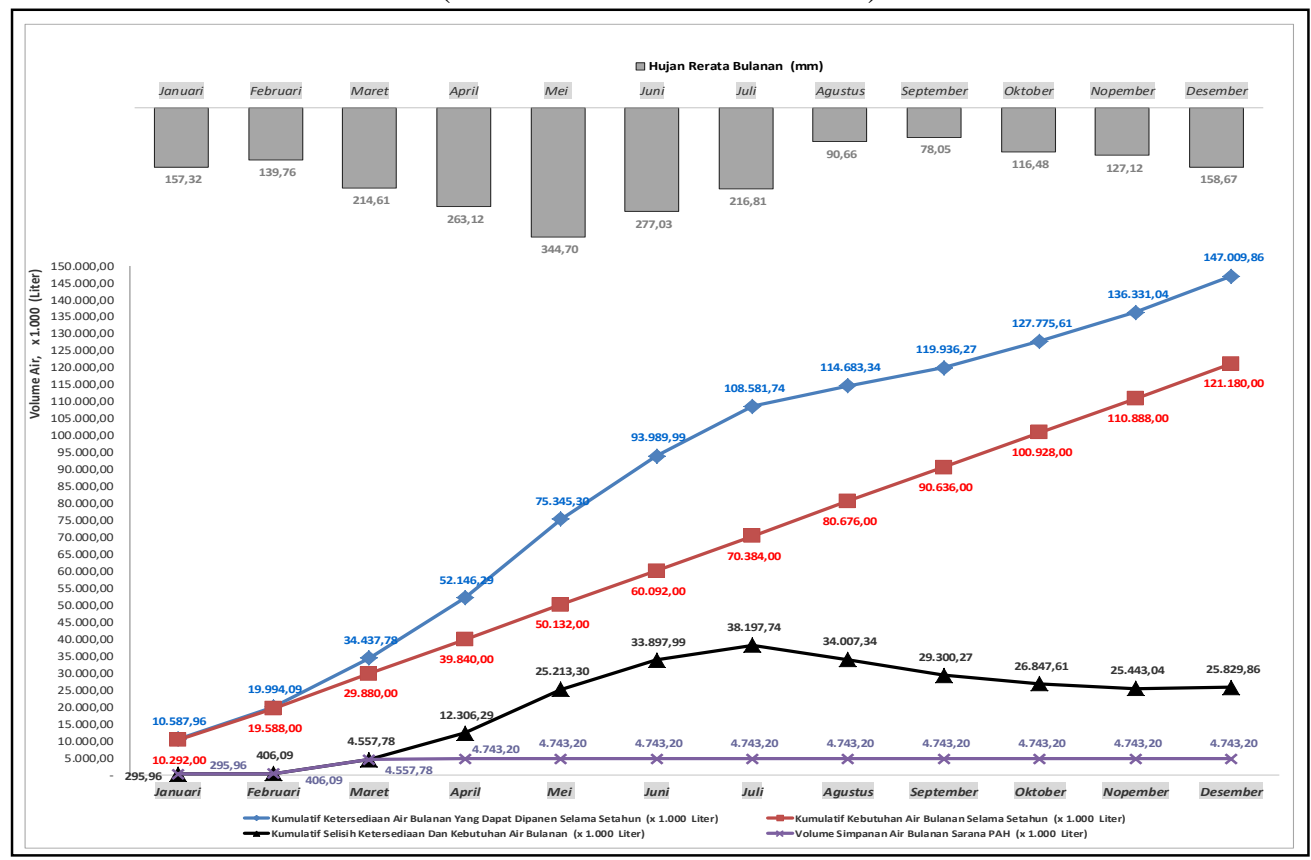

Gambar 4. Hubungan Antara Kumulatif Ketersediaan Air Hujan, Kumulatif Kebutuhan Air Bersih, Kumulatif Selisih Ketersediaan - Kebutuhan

Serta Kumulatif Volume Simpanan Air Hujan Yang Dapat Tersimpan

Dalam Sarana PAH Dalam Setahun (Sumber: Hasil Analisis. 2016) 


\section{Evaluasi Sistem Jaringan Drainase Eksisting}

Evaluasi kapasitas sistem jaringan drainase yang dimaksud mencakup dua macam, yaitu evaluasi kapasitas saluran drainase dan evaluasi kapasitas gorong-gorong. Tujuan evaluasi ini adalah untuk melihat apakah dengan dimensi saluran yang ada masih mampu untuk mengakomodir limpasan yang terjadi tanpa mengakibatkan overflow pada jalan, atau lahan perumahan yang ada di sekitarnya.

Dari hasil evaluasi, dapat disimpulkan bahwa mayoritas kapasitas dari saluran dan gorong-gorong yang ada saat ini, tidak memadai atau tidak mencukupi untuk mengakomodir besar debit rencana limpasan yang akan terjadi ketika hujan rencana kala ulang 5 (lima) tahunan benar-benar terjadi. Dari total 77 ruas saluran tersier, terdapat 23 ruas saluran yang mengalami overflow, 28 ruas dari 33 ruas saluran sekunder atau kolektor, serta 9 ruas dari total 10 ruas saluran pembuang utama. Sementara, untuk gorong-gorong, terdapat 34 titik dari total 43 titik gorong-gorong yang akan mengalami overcapacity.

\section{Evaluasi Penerapan Sistem PAH Dalam Mereduksi Limpasan}

Dengan adanya penerapan sistem PAH yang terintegrasi dalam sistem drainase perumahan, berdasarkan hasil analisis, akan mampu mereduksi jumlah limpasan yang harus diakomodir oleh saluran dan gorong-gorong drainase eksisting, tanpa harus merubah dimensi yang ada, sebesar $85,38 \%$, yakni $7835,814 \mathrm{~m}^{3}$ dari $9178,032 \mathrm{~m}^{3}$ total limpasan yang terjadi.

Hasil analisis juga menunjukkan bahwa untuk saluran tersier seluruh ruas yang ada (77 ruas) akan mampu untuk menampung sisa limpasan yang terjadi (setelah direduksi oleh sistem PAH), dengan kata lain dimensi eksisting masih memadai/mencukupi untuk menampung debit aliran (efisiensi pengurangan sebesar 100\%). Sementara untuk saluran sekunder atau kolektor, dari total 33 ruas saluran yang mengalami overflow dapat dikurangi menjadi 14 ruas (efisiensi pengurangan sebesar $58 \%$ dari jumlah saluran overflow sebelum penerapan sistem $\mathrm{PAH}$ ), dan untuk saluran pembuang utama, dari 10 ruas yang sebelumnya mengalami overflow berkurang menjadi 6 ruas $(40 \%$ dari jumlah sebelumnya). Adapun untuk gorong-gorong, jumlah pengurangan hanya sebesar $29 \%$ saja, yaitu dari total 34 titik gorong-gorong yang sebelumnya mengalami overcapacity, dengan adanya penerapan sistem PAH, akan dapat tereduksi menjadi 24 titik.

\section{Usulan Penanganan Sisa Overflow Limpasan Setelah Penerapan Sistem PAH}

Untuk menangani sisa overflow yang masih terjadi setelah penerapan sistem PAH di lokasi studi, maka diusulkan beberapa hal, sebagai berikut:

1) Rehabilitasi saluran tanah (saluran yang rusak) menjadi pasangan batu, yakni saluran-saluran tersier di sub-blok $\mathrm{Aa}, \mathrm{Ab}$, B1a.1，B2b，B2a， B2c-s，B2d-u，B4, saluran-saluran sekunder ruas B3a, B3b, B3d, B2a, B2b, B2c.I, B2d, B2c.II, dan saluran-saluran pembuang utama ruas $M$ dan ruas D1d.

2) Penambahan tinggi minimal $20 \mathrm{~cm}$ pada saluran yang terletak di ruas-ruas jalan yang masih berupa perkerasan sirtu, dengan asumsi ruas-ruas jalan tersebut akan mengalami penambahan tinggi ketika di-upgrade menjadi jalan beton atau jalan perkerasan paving block.

3) Modifikasi kemiringan saluran pasangan batu yang terlalu landai, dan disesuaikan dengan kemiringan ruas saluran yang ada di hulu atau hilirnya, namun tetap memperhatikan elevasi pipa outlet pembuangan rumah tangga penduduk, yakni pada saluran-saluran sekunder ruas E1c, E1b, E1a dan saluran-saluran pembuang utama ruas $\mathrm{Da}, \mathrm{Db}$, Dc dan Dd.

\section{Perencanaan Prasarana (Fasilitas Pelengkap) PAH Atap}

Prasarana (fasilitas pelengkap) PAH yang dimaksud adalah talang air (gutter), pipa penghantar vertikal (downspout pipe) dari talang ke sarana $\mathrm{PAH}$, serta pengalih limpasan pertama (first-flush diverter).

Dari hasil perencanaan fasilitas prasarana PAH atap untuk rumah tipe 36/96 (mayoritas tipikal rumah yang ada di lokasi penelitian), diperoleh:

1) Talang yang digunakan adalah talang persegi yang terbuat dari lembaran besi galvanis plat, dengan ukuran minimum $0,20 \mathrm{~m}(\mathrm{~B}) \times 0,20 \mathrm{~m}(\mathrm{H})$.

2) Untuk pipa penghantar vertikal digunakan Pipa PVC Diameter 3" dengan tinggi jatuh maksimum (H) 3,25 m dari bawah talang. 
3) Untuk fasilitas pengalih limpasan pertama digunakan Pipa PVC Diameter 4" dengan panjang minimum $2,20 \mathrm{~m}$.

\section{Rekomendasi Teknis Pemanfaatan Sistem PAH Dan Pembenahan Sistem Jaringan Drainase}

Berdasarkan hasil kajian dan analisis teknis, dapat dirumuskan beberapa rekomendasi sebagai berikut:

1) Untuk memenuhi kebutuhan air bersih penduduk yang ada di kawasan perumahan, yakni sebesar 100 liter/hari/orang, maka diusulkan untuk setiap rumah menggunakan sarana $\mathrm{PAH}$ dengan kapasitas rencana sebagaimana dalam Tabel 3.

Selain sebagai sarana penyimpanan air untuk keperluan konservasi, pada kondisi dimana terjadi hujan-hujan ekstrim (musim penghujan) yang di dekati dengan hujan rencana kala ulang 5 tahunan, sarana $\mathrm{PAH}$ yang akan digunakan tersebut juga akan menjadi reduktor limpasan yang terjadi sehingga sedikit banyak akan mengurangi beban saluran dalam mengakomodir limpasan yang terjadi, sehingga akan mengurangi luapan (overflow) baik yang terjadi pada saluran maupun pada gorong-gorong seperti yang selama ini terjadi di beberapa ruas saluran yang ada dalam Perumahan Bone Biru Indah Permai Kota Watampone. Namun demikian, tidak semua luapan (overflow) akan terakomodir oleh kapasitas saluran dan gorong-gorong yang ada saat ini. Untuk itu, direkomendasikan untuk dilakukan pembenahan (rehabilitasi) pada beberapa ruas saluran yang membutuhkan adanya perbaikan.

2) Untuk pemilihan fasilitas penunjang (sarana PAH) khususnya untuk rumahrumah bertipe 36/96, direkomendasikan menggunakan talang air persegi yang terbuat dari; lembaran besi galvanis plat dengan ukuran minimum $0,20 \mathrm{~m}$ x 0,20 $\mathrm{m}$; pipa penghantar vertikal yang terbuat dari Pipa PVC Diameter 3" dengan tinggi jatuh maksimum (H) 3,25 m dari bawah talang.; serta fasilitas pengalih limpasan pertama yang terbuat dari Pipa PVC Diameter 4" dengan panjang minimum $2,20 \mathrm{~m}$, untuk setiap rumah.

\section{KESIMPULAN}

Dari hasil studi dapat disimpulkan sebagai berikut:

1) Potensi air hujan yang dapat disimpan oleh rainwater harvesting system (sistem pemanenan air hujan (PAH)) di Perumahan Bone Biru Indah Permai Kota Watampone adalah sebesar 147.009.856,03 liter $\left(147.009,86 \mathrm{~m}^{3}\right)$ dalam setahun. Jumlah air bersih yang dibutuhkan oleh penduduk perumahan untuk keperluan domestik selama setahunnya (dengan kebutuhan air bersih harian sebesar 100 liter/hari/orang), yakni sebesar 121.180.000,00 liter $\left(121.180,00 \mathrm{~m}^{3}\right)(82,43 \%)$. Sehingga, sisa volume hujan sebesar 25.829.856,03 liter $\left(25.829,86 \mathrm{~m}^{3}, \quad 17,57 \%\right)$ dan harus diakomodir oleh sistem drainase perumahan (ditambah dengan limpasan yang berasal dari jalan dan lahan yang ada di perumahan).

2) Total kapasitas sarana PAH yang dibutuhkan sebesar 4.743.200,00 liter $\left(4.743,20 \mathrm{~m}^{3}\right)$. Teknis penyimpanan air hujan dilakukan dengan menggunakan sarana PAH yang ter-install di masingmasing rumah yang ada di setiap subbloknya (individu). Penyimpanan secara kolektif tidak dianjurkan, mengingat keterbatasan ruang yang ada dan dalam rangka menghindari biaya konstruksi yang besar. Pemanfaatan air hujan yang tersimpan dilakukan dengan cara konsumsi bulanan dalam memenuhi kebutuhan yang sifatnya non-potable, sehingga air yang ada dalam kolam tampungan dapat terus bersirkulasi setiap bulan selama setahunnya.

Adapun saran yang dapat diberikan terkait penelitian selanjutnya adalah:

1) Penggunaan software-software yang relevan dengan topik kajian (seperti EPA SWMM, dll).

2) Adanya penelitian terhadap kandungankandungan fisik dan kimiawi dari air hujan yang jatuh, sehingga dihasilkan suatu rekomendasi apakah air yang dipanen oleh sistem PAH dapat dijadikan sebagai sumber air minum atau tidak, dan jika diperlukan, metode-metode pengolahan air baku yang bagaimana, yang cocok untuk diterapkan sesuai dengan kondisi perumahan ini. 


\section{UCAPAN TERIMA KASIH}

Penghargaan yang sebesarnya penulis sampaikan kepada segenap pimpinan dan jajaran Balai Besar Wilayah Sungai Pompengan Jeneberang Makassar, Dinas Sumber Daya Air Propinsi Sulawesi Selatan, dan Dinas Pekerjaan Umum dan Sumber Daya Air Kabupaten Bone, serta seluruh pihak yang telah membantu terselenggaranya penelitian ini. Terkhusus kepada Kementerian Pekerjaan Umum melalui Balai Pengembangan Sumber Daya Manusia yang telah memberikan bantuan dana beasiswa melalui program vokasi pendidikan kepada penulis.

\section{DAFTAR PUSTAKA}

Andawayanti, U dan Prasetyorini, L. 2007. Analisis Volume Genangan Terhadap Perubahan Penggunaan Lahan dan Penanggulangannya berbasis Konservasi Lingkungan (Studi Kasus di Kecamatan Kepanjen). Jurnal. Malang.

Anonim. 2012. Rainwater Harvesting Best Practice Guidebook: Residential Rainwater Harvesting Design and Installation. Kanada: Regional District of Nanaimo, Nanaimo, B.C.

Asdak, C. 2002. Hidrologi dan Pengelolaan Daerah Aliran Sungai. Yogyakarta: Gajah Mada University Press.

Badan Pusat Statistik (BPS) Kabupaten Bone. 2015. Kabupaten Bone Dalam Angka 2015. Watampone: CV21.COM.

Brown, S.A, Schall, J.D, Morris, J.L, Doherty, C.L, Stein, S.M, dan Warner, J.C. 2009.
Urban Drainage Design Manual. Hydraulic Engineering Circular 22. $3^{\text {rd }}$ Edition Washington: Federal Highway Administration \& National Highway Institute. US. Department of Transportation.

Department of Environment, Food, and Rural Affairs (DEFRA). 2011. National Standards for Sustainables Drainage Systems. Designing, Constructing, Operating and Maintaining Drainage for Surface Runoff. London. United Kingdom.

Direktorat Jenderal (Ditjen) Cipta Karya. 1996. Kriteria Perencanaan Analisis Kebutuhan Air. Jakarta: Direktorat Jenderal Cipta Karya.

Kementerian Pekerjaan Umum. 2014. Peraturan Menteri Pekerjaan Umum Republik Indonesia Nomor 11/PRT/M/2014 Tentang Pengelolaan Air Hujan Pada Bangunan Gedung dan Persilnya. Jakarta: Kementerian Pekerjaan Umum.

Suhardjono. 2015. Drainase Perkotaan. Buku Ajar. Tidak diterbitkan. Malang: Universitas Brawijaya.

Suripin. 2004. Sistem Drainase Perkotaan Yang Berkelanjutan. Yogyakarta: ANDI.

United Nations Environment Programme (UNEP) dan Caribbean Environmental Health Institute (CEHI). 2009. Rainwater. Catch it While You Can: A Handbook on Raunwater Harvesting in the Caribbean. Tidak diterbitkan. 